\title{
MIS-EDUCATION, TRANSLATION AND THE BARKADA OF LANGUAGES: READING RENATO CONSTANTINO WITH NICK JOAQUIN
}

\author{
Vicente L. Rafael \\ University of Washington, Seattle \\ vrafael@uw.edu
}

\begin{abstract}
This paper re-visits the classic piece by Renato Constantino, "The Mis-education of the Filipino" (1959/1966), inquiring into the colonial basis of his anti-colonial critique of American English. It explores the affinity between his view of language and those of American colonial officials, especially around the relationship between English and the vernacular languages. Both conceived of that relationship in terms of a war of and on translation. It then turns to an important but overlooked essay by Nick Joaquin published around the same time as Constantino's, "The Language of the Streets" (1963). By closely considering Joaquin's views on "Tagalog slang" as the basis for a national language, we can see a different politics of language at work, one based not on translation as war but as play. Whereas Constantino was concerned with language as the medium for revealing the historical truth of nationhood that would lead to democratizing society, Joaquin was more interested in the conversion of history into language as a way of expanding literary democracy.
\end{abstract}

\section{About the Author}

Vicente L. Rafael is Professor of History at the University of Washington in Seattle. He grew up in Manila and graduated from the Ateneo in 1977. His books include Contracting Colonialism: Translation and Christian Conversion in Tagalog Society Under Early Spanish Rule (1993), White Love and Other Events in Filipino History (200o), and The Promise of the Foreign: Nationalism and the Technics of Translation in the Spanish Philippines (2005). He is currently at work on a book on translation, war and the historical imagination between the Philippines and the US. 


\section{American English and National Death}

Renato Constantino (1919-1999) wrote his classic essay, "The Mis-education of the Filipino" in 1959 but could not get it published until 1966. This long time lag is not surprising given the widespread persecution of the left and the hostile climate for anti-American critiques of any sort throughout the 1950s. The Cold War raged on while the embers of the Huk rebellion were still glowing. Constantino's left-wing sympathies emerged while he was a student at the University of the Philippines from 1936-1941. It deepened in the face of his guerilla activities during the Japanese Occupation and found full expression in his post-war journalism. Serving as part of the Philippine delegation to the United Nations in New York from 1947-49, he became even more critical of what he perceived as United States' imperial designs on the Third World. Back in Manila, Constantino found himself caught up in the anti-communist witch hunts. In 1951, his father-in-law's home, where he and his wife were living, was raided by agents of the Military Intelligence Service (MIS). Though he escaped detention, Constantino lost his job with the Department of Foreign Affairs. He was blacklisted for several years, prevented from getting any regular academic appointments and barred from publishing except for a brief period from 1957-59. It was then that he developed a close friendship with the ilustrado nationalist and senator, Claro M. Recto and with the Visayan sugar baron and media magnate, Eugenio Lopez (a friend of his father-in-law, Mamerto Roxas who in turn was the brother of former Philippine president, Manuel Roxas). Both interceded on his behalf and protected him from military persecution. But in 1961, the harassment picked up again. Constantino was accused of being a member of the Partido Komunista ng Pilipinas (PKP), which he denied, and was investigated by the McCarthy-inspired House Committee on Anti-Filipino Activities (CUFA). ${ }^{1}$

It was not until 1966 that the editor at the newsmagazine, The Weekly Graphic (which had just been purchased by the wealthy land owner J. Antonio Araneta) finally published his essay. By then, Constantino had become the Director of the Lopez Museum and Library, a position he held until the early 1970s. He had also become a highly visible public intellectual at a time of nationalist ferment, especially on the left. The Kabataang Makabayan had been organized just two years earlier, while the broad-based though short-lived Movement for the Advancement of Nationalism (MAN) was to be established the following year and the new Maoist Communist Party of the Philippines was to come the year after that. While he was never formally a member of any of these groups, he was nonetheless acknowledged as a major intellectual inspiration by many of their members. His essay also appeared at a moment when radical changes were unfolding across the world-revolution and decolonization in the Third World; civil rights and women's liberation movements in the Americas; workers and student strikes across in Europe and the US; and counter-cultural currents and new social movements everywhere else. At the cusp of the revolutionary domestic and international developments, 
"The Mis-education of the Filipino" quickly became a touchstone for addressing what came to be known as the neo-colonial condition of the Philippines. "The response was tremendous," Constantino remarked in an interview. It has since been republished numerous times and continues to be widely read to this day in the Philippines and elsewhere. ${ }^{2}$ Much of the essay recapitulates a set of ideas that Constantino began formulating as far back as the late 1930s while he was editor of the Philippine Collegian at UP and which he continued to elaborate in his postwar articles for various newspapers. Though inflected with a Marxist sensibility, his essay was influenced primarily by the anti-American arguments of his mentor, Recto, as well as by some aspects of Jose Rizal's romantic nationalism. But as I hope to show, it also bore a surprising affinity with American colonial discourse, both critical and supportive, of the public educational system from the 1920 and 30 s. $^{3}$

According to Constantino, if the Philippines remained economically underdeveloped, socially divided, politically corrupt and culturally bankrupt, it was largely because of the fact that it continued to be a colonial appendage of the United States. Two decades after Independence, the country's dependency on America had intensified. Not only did Filipinos continue to be subservient to their former colonial masters. Worse, they craved their subservience. For this "shameful" condition, Constantino places blame squarely on the country's educational system. Run by foreigners, foreign-trained Filipinos, or worse, by an authoritarian clergy, Philippine schools, he claimed perpetuated the work of colonial education. They fostered uncritical views of the benevolence of the United States, training Filipinos to blindly embrace American models. "Nurtured in this kind of education," he wrote, "the Filipino mind has come to regard centuries of colonial status as a grace from above rather than a scourge" (29). Rather than enlighten students, schools were guilty of furthering their state of tutelage. They thus educated students by miseducating them, leading students to believe that they could be modern by being "little Americans." Students were consigned to the impossible task of seeking what they could never attain by trying to become other than who they were supposed to be. In this way, colonial education foreclosed their future. It kept them ignorant, holding the country in a state of abject backwardness. While other Asian countries were then vigorously promoting their national cultures along with their national economies, the Philippines continued to disavow its distinctiveness. Deferring to America, they were deluded into thinking of themselves as exceptional Asians: as "Filipino Americans." In short, schools produced subjects incapable of knowing themselves much less understanding the "basic ills" of their country. Barred from the truth of their being, they were deprived of the proper knowledge of their past marked by imperial injustice and anti-colonial struggles. As such, Filipinos could not be redeemed for the future.

The "tragedy" of mis-education thus revolves around the frustration of a nationalist teleology. The dialectic of nationalist history tends to idealize history. Colonial conquest is supposed to beget anti-colonial resistance which in turn 
is expected to give birth to a sovereign people steeped in the righteousness of their struggle and the knowledge of their destiny. This is the truth of nationalism, the justice of its cause. Mis-education has concealed and distorted such a truth inasmuch as schools collaborate in carrying out American designs. For Constantino, the chief tool for bringing about the tragedy of mis-education is the very language of instruction, English. The hegemony of English-its power to shape thinking and constrain dissent-stems from its historical deployment as a weapon of colonial conquest. Constantino writes that,

in exchange for a smattering of English, we yielded our souls. The stories of George Washington and Abraham Lincoln made us forget our own nationalism. The American view of our history turned our heroes into brigands in our own eyes, distorting our vision of the future. (23)

Colonial education consists of a Faustian bargain: knowledge of English and American history in exchange for "our souls," and with it, our language and our past. As the "master stroke" of colonial education, the use of English as the sole medium of instruction has had the effect of "separate[ing] the Filipinos from their past" while dividing "educated Filipinos from their countrymen" (24). Thanks to English, native students were "introduced to a strange new world . . . alien to their traditions. . . . This was the beginning of mis-education, for they learned no longer as Filipinos but as colonials. . . [as] the carbon copies of [their] conqueror" (24). Rather than unify native societies by providing a common language, English intensified social divisions while promoting historical amnesia. An alien language, it could only produce alienating effects. It turned natives neither into Filipinos nor Americans but into copies of the latter. Thus did natives become triply displaced: not only from whom they had been as native peoples, and from what they were destined to be as national subjects, but also from what they were taught to become but were barred from achieving, as faithful copies of their colonial masters.

Sent ontologically adrift by English, natives could only grasp a "distorted" view of their history: "The history of our ancestors was taken up as if they were a strange and foreign people who settled in these shores. . . We read about them as if we were tourists in a foreign land" (24). English thus completes the task of conquest by imaginatively displacing the native from his own land. Compelled to speak the master's tongue, the native actively identifies and collaborates in this displacement. As "tourists," she confronts her own past as if it were someone else's, just as she regards her own land as a transient possession, as if she were renting it from some other owner. So, too, with her native tongue. Learning English has meant suppressing the vernacular language. Here, it is worth recalling that as late as the 1960s, students were routinely fined five or ten centavos by teachers who caught them conversing in their native languages in school. Still, the fact remains, Constantino argues, that English could never take the place of the vernacular. It 
has instead remained irreducibly foreign, incapable of finding a proper home among Filipinos. The foreignness of English comes not only with its association with conquest but also through its very agents of transmission. Early on, American teachers taught the language but were eventually replaced by Filipinos for whom English was at best a second and often imperfectly spoken language.

For this reason, education in English has produced an intolerable linguistic and social situation. On the one hand, students are unable to master the master's speech inasmuch as its sounds, references and nuances remain outside of their experiences. On the other hand, they have lost their capacity to speak their mother tongue which has been forbidden to them. Bereft of fluency in any language, students are unable to think and express themselves except in the most "mechanical way." This makes for a "deplorable lack of serious thinking" in society. "We half understand books and periodicals written in English. We find it an ordeal to communicate with each other through a foreign medium, and yet we have so neglected our native language that we find ourselves at a loss in expressing ourselves in this language" (33). The bio-political consequences of this situation had been nothing short of disastrous. Having failed in its function as a lingua franca, English lets leaders speak only "in general and vague terms" while reducing the masses to a state of inarticulateness, incapable of "expressing itself in any language" (31). Originally envisioned as a medium for democratizing society, English has proven to be a "barrier" to such a project. Hence, not only does English produce historical forgetting. By suppressing native speech while remaining foreign to native speakers, English sets the condition for the self-annihilation of the Filipino people.

For Constantino, then, to embrace a foreign language instead of one's own is tantamount to signing the nation's death warrant. He takes this notion from no less than the national hero, Jose Rizal. It is uttered by one of his most memorable and fearsome characters, the ilustrado turned anarchist, Simoun in his second novel, El Filibusterismo (1891). Disillusioned by the failure of liberal reforms and hounded to wander the world by his enemies, Simoun secretly returns to the Philippines to plot his revenge. In one scene, he reveals his true identity to the student Basilio who still believes in the possibility of reforms which includes teaching Spanish to all Filipinos. For this generation of ilustrados, including Rizal himself, spreading Spanish was a way of achieving the enlightenment and progress they believed they were entitled to. What stood in their way were the Spanish friars. The latter opposed mass literacy in Spanish, fearing that it would undermine their monopoly over the means of communication in the colony. Since the start of colonization, the Spanish clergy had decided to convert and preach to the native peoples in their vernacular languages, while the colonial state used Spanish. This made the priests indispensible interpreters, capable of transmitting the words of those above to those below and vice versa. For Filipino ilustrado nationalists, mass literacy in Spanish held the promise of overcoming the mediating power of the friars. It was a way out of the oppressive parochialism of colonial rule and the way into a more 
cosmopolitan world of liberty and justice. Spanish would furnish the emergent nation with a lingua franca-common to all because native to no one-that would directly connect the people with their leaders and with one another. Nationalism based on Spanish would mean bypassing the "anti-modern" interference of the Spanish clergy. ${ }^{4}$ Simoun, however, rejects this entire line of argument. Constantino approvingly cites his disdainful retort:

You ask for equal rights, the Hispanization of your customs, and you don't see that what you are begging for is suicide, the destruction of your nationality, the annihilation of your fatherland, the consecration of tyranny! What will you be in the future? A people without character, a nation without liberty. Everything you have will have been borrowed, even your defects! What are you going to do with Castilian, the few of you who will speak it? Kill off your own originality, subordinate your thoughts to other brains, and instead of freeing yourselves, make yourselves slaves indeed!. . . . He among you who talk that language neglects his own in such a way that he neither writes it nor understands it. . ${ }^{5}(30)$

In citing this passage, Constantino channels the outraged energy of Simoun and imagines the destructive effects of a foreign language allowed to dominate the native tongue. From this perspective, learning the master's language can only deepen the enslavement of the native, "killing off" what makes him a free and original subject deciding on his future. Mis-education thus climaxes with the suicide of the native who abandons herself to the very forces that negate her. Writing in English, the nationalist author warns of its fatal consequences. For English can only render the native immune to the very source of her life, which is her mother tongue and in so doing can only lead to her self-destruction. "What Rizal said about Spanish," Constantino writes, "has been proven to be equally true for English" (30).

Has it? Does the promise of a foreign, colonial language always invariably turn out to be a curse? Does it always lead to the self-destruction of the mis-educated? Or can mis-education give rise to something and someone different other than the suicidal colonized subject? Are there ways by which the nation can survive, perhaps even transform its mis-educated state? Can the desire, even if it is forever deferred for a foreign language, the master's speech, bring about not death but another form of life? And could we think of this life as one that, while steeped in the history of the colonial, also escapes it? And in escaping it, also revises the tragic vision and unfinished history of the national?

In the latter section of Constantino's essay, we get a hint of this other possibility. Rather than the self-inflicted death of a failed national subject, English could also produce "appreciation" from the masses. "Because of their lack of command of English, the masses have gotten used to only half-understanding what is said to them in English. They appreciate the sounds without knowing the sense. This is 
a barrier to democracy" (31). Confronted with foreign words, the masses fail to grasp their meaning but nonetheless "appreciate" their sonic qualities. They are drawn to the sensuous features of English and see in them a certain attraction. Constantino laments the failure of the masses to fully understand what is said to them. He assumes that this means they cannot speak back, thus hindering their political participation. The masses seem more interested in apprehending rather than comprehending English. They are compelled less by its meaning than by its materiality, or perhaps conflate the one with the other. Such a response suggests a stance towards English at variance with nationalist expectations. In privileging sound over sense, the masses, whoever they are, seem to find a way to make room for English alongside rather than on top of the vernacular, translating its strangeness from a menace into a resource. How is this possible? Is there another history working within colonial education that might allow us to see this other kind of relationship with English?

\section{Colonial Schooling and the Monstrosities of Filipino Speech}

In 1924, the Lebanese-American colonial official and scholar Najeeb Saleeby published a series of lectures he delivered in Manila on the problem of English language education. Constantino quotes approvingly from Saleeby to support his argument about the inherent inability of English to serve as a lingua franca for democratizing the country. But a closer reading of these passages suggests that Saleeby was not just critical of colonial efforts to use English as the sole medium of instruction in schools. He was equally impressed by the power of the vernacular languages to withstand the deployment of English. Just as "three centuries of Spanish rule...failed to check the vernacular... twenty five years of intensive English education has produced no radical change. More people at present (i.e., 1924) speak English than Spanish, but the great majority hold on to the local dialect" (qtd. in Constantino 32). Writing about forty years before Constantino, Saleeby tells a slightly different story. Where Constantino sees only the overwhelming victory of colonial education and the unquestioned hegemony of English, Saleeby sees the inability of English to take hold in schools and regards this as a sign of the failure and hubris of American colonial policy. Even more significant, while Constantino bemoans the neglect of the vernaculars in the face of English, Saleeby remarks on the tenacity of native languages which students hold on to in the face of English. In reading Saleeby, we get a sense that the vernacular could not be repressed. Efforts to supplant it with English produced effects other than those intended by colonial educators and denounced by the nationalist intellectual. It is to these other effects that I now want to turn to.

Contemporaneous American critiques of colonial education like Saleeby's similarly anticipate nationalist views like Constantino's. In 1925, for example, the 
Board of Educational Survey commissioned by the all-Filipino colonial legislature produced a massive report, Survey of the Educational System in the Philippines. ${ }^{7}$ Headed by Paul Monroe of Columbia University, the Survey sought to assess the conditions of public schooling especially in the wake of the Jones Law of 1916 that had mandated the swift Filipinization of the colonial bureaucracy including those related to public education. Like Saleeby and Constantino, the Survey was roundly critical of public schooling. It was especially dismayed at the teaching of English. As "the most critical issue in the Philippine school situation," the Survey devotes detailed attention to investigating the "obstacles" that stood in the teaching of English (115). While the Survey was impressed by the enthusiasm of Filipinos for schools where attendance was free and non-compulsory, it was far more disappointed by the inability of Filipino teachers and students to develop a working fluency of American English. In accounting for this failure, it mentions a number of reasons ranging from the acute shortage of American teachers (roughly one percent of the teaching personnel by 1920) to the inadequate training of Filipino teachers. The small numbers of American teachers meant that there was little opportunity to correct Filipino teachers who as non-native speakers of English were prone to transmit and consolidate errors of grammar and pronunciation to their students.

But the most significant obstacle to gaining fluency in English according to the Survey was the vernacular languages themselves. Over and over again, the Survey complains about the great disadvantage faced by English forced to compete with the native languages. Children enter school after seven or eight years of speaking their mother tongue. Physically attuned and mentally habituated to its intonations, referents and rhythm, they are then expected in school to switch over to an entirely different foreign language. Such a sudden transition, according to the Survey, has the effect of deterring children from learning. The task of learning English which entails unlearning the vernacular, takes them away from the task of learning as such. They are thus burdened with the demand to speak otherwise as a prerequisite to being able to speak at all. In this way, English creates a kind of disability. It constitutes what the Survey calls a "foreign language handicap":

The foreign language handicap...is from the start a serious obstacle to success in teaching. From the day a Filipino child enters school he is confronted by the double necessity of mastering a strange tongue and of carrying out school work in it. At no time in his career does he encounter the single task of studying in his mother tongue. He is required to read not in Visayan, not in Tagalog, not in Ilocano, not in Bicol-but in English. He faces the necessity of mastering the intricacies of oral speech in a language almost completely unphonetic and totally removed in accent, rhythm, tonal expression and phonetic organization from the one which he hears on the playground, at home and in the community. During seven years of childhood... he has acquired the difficult coordinations [sic] 
of pronunciation of his native dialect. When he enters school he must disregard and attempt to blot these out of his habit system.... Not only do the old habits fail to facilitate but they actually inhibit the acquisition of new ones. (127)

Coming to school meant leaving the home, stepping into a foreign space dominated by the other's speech. One left one's mother and mother tongue to stand before a foreign language. One was exposed to the specific, exacting demands of the foreign for several hours a day, forced to conform one's body and voice to its commands and expectations. Submission to the rigors of English, however, was deemed as a way of eventually mastering it. Confronting the other's speech, one was trained to conquer it, to possess it and make it an integral part of oneself. The goal of mastery, however, proved elusive. The child was put at a permanent disadvantage by the historical purchase of the vernacular. She was handicapped in view of the persistent influence of the mother tongue which established a formidable barrier to the learning of the other tongue. In school, the child was expected to engage in a veritable war of separation. She was supposed to "disregard and...blot out" the habits of speech from home. To speak English meant repressing the vernacular. Such entailed exchanging the body at home with the first language for a new body capable of conquering a second tongue. Put differently, learning English required the labor of translation. Compelled to substitute the first "premodern" language for a second "modern" one, the child was expected to perform the work of translation as the essential prelude to learning. The problem, according to the Survey was that for the Filipino student, translation never ceased. "If he is to come from the school a well trained thinker, he must be taught to think in a foreign language. The handicap of translation must be overcome" (128).

The "foreign language handicap" turns out to be the handicap of translation. For learning to occur, translation must be overcome. Indeed, it was precisely the problems posed by translation that shaped the American decision to use English rather than Spanish or the native languages as the sole medium of instruction. Fred Atkinson who served as the first Superintendent of Public Instruction from 1901 to 1902 initially considered using the native languages for the primary grades, but quickly changed his mind, saying that such a move would be "impractical [since] it would necessitate the setting of large corps of translators at work, putting not merely school primers but large numbers of books of every sort into all the principal dialects." Neither would Spanish do since "only a small portion of the native population understood much Spanish," and almost no Americans could be found who could teach in that language. ${ }^{8}$ English as the "practical" alternative to other languages implied two things. First, it meant that Americans were saved from the necessity of learning Spanish or the native languages. Instead, they shifted the burden of translation onto Filipinos. As native speakers of English, Americans were exempt from the taxing demands of having to speak otherwise, remaining 
comfortably monolingual. Second, Americans thought that by teaching Filipinos English, they were endowing the latter with a common language. Learning English would enable natives to move out of their first into a second language with which to reach across linguistic and social divisions. Thus would they come to have something in common not only with one another but with those who ruled them. English would allow them to communicate directly with anyone in the country without resorting to another language. In this way, they would be freed from the need to translate from one language to another. Once fluent in English, Filipinos would become like Americans, relieved from the arduous task of translating. The "practicality" of teaching English therefore had an ideological dimension.

Realizing this goal, however, proved practically impossible thanks to the workings of the vernacular. "During the years in which children are struggling with the new language... their efforts are being combated constantly by the pervasive influence of the dialect with which they are surrounded in all their out of school hours" (40). The child finding herself assailed by English in school can hope to find relief with the vernacular at home. Back in school, however, the child finds herself plunged into an asymmetrical war with English. She is forced to translate in a particular way, by suppressing her first in favor of a second language. Translation as such was meant to allow the child to eventually dominate the language that had until then dominated her. Suppressing the vernacular and gaining fluency in English were thus conceived as part of a single movement that would enable the student to think in the other language. Thinking, in turn, meant no longer having to translate. Overcoming the "handicap" of translation meant making the foreign familiar rather than merely fearsome, taming it into an instrument of one's thought and a ready servant of one's expression.

Created as a counterinsurgent response to the Filipino-American war, colonial education sought to train colonized subjects in a different sort of war. We might think of this as the war of translation. The pursuit of this war aimed at the conquest and colonization of languages, both the vernaculars and English. As we have seen, mastering the second required setting aside the first. School was the site for the production and consolidation of this linguistic hierarchy. The student learned to translate by way of putting the mother tongue in its place, under the domination of a foreign one, thereby coming to dominate the foreign language herself. Winning this double victory would then transform the student into a new subject standing atop and in control of the linguistic hierarchy. Colonizing both languages, holding each to their respective places, the educated subject can now command language itself in the service of her thoughts and expressions. Doing so meant putting an end to the labor of translation or at least minimizing its visibility which could only detract from the appearance of thought. The war of translation was thus also meant to be a war on translation. It would conclude in the unequal peace among languages that would establish the rule of the thinking subject over the means and materials of its production. 
The Survey makes clear, however, that the aims of colonial education were far from being realized. There seemed to be no end to the war of translation. English remained foreign and external to students while the vernaculars refused to keep to their place. In fact, it seemed to the Americans that the very attempt to teach English simply inflamed the resistance of the native languages. The insurgent energy of the vernaculars was most visible and audible in their insistent claims on the bodies of the Filipino teachers and students. The vernaculars' capacity to infiltrate the scene of instruction became particularly palpable to the Americans when they heard the "Filipinized English" recited daily in the classrooms. Again and again, the Survey remarks on what to them appeared to be errors that came with Filipino attempts to speak English. It begins with the Filipino teacher. Lacking in training, she addresses her students,

in strange words, words clothed, however, in the familiar...monotone of the Malayan dialects. Be their native tongue Tagalog, Ilocano, Bicol, Visayan, Pampangan [sic], what not, the teachers of the Islands are passing on to the children partial English pronunciations set in the rhythm and cadence of their own tongues. It is our judgment that this setting of Malay rhythm, accent and syllabication is the chief source of unintelligibility... The Filipino child learns to attach meanings to familiar objects and actions which have been named by his teacher in strange sounding words. He listens to the new sounds; he tries to utter them. He hears these strange English words uttered with the familiar Filipino intonation. (155)

Hearing the teacher's English, the student follows. But doing so, she is misled, perhaps mis-educated, taking a different path. She ends up not on the road to phonetically correct American English but to the "strange and "unintelligible" zone of its Filipinized version. "Filipinized English" here consists of dressing English in the clothes of "Malay" sound patterns. It is a kind of English that perplexes the authors of the Survey. Students addressed in Filipinized English readily recognize the vernacular shaping the materiality of foreign words, and it is this recognition that allows them to follow the teacher's voice. They see in the foreign the recurrence of the vernacular, not its demise. To translate in this case requires not the suppression of the first for the second language, but an alertness to the sound of the first retracing itself around the appearance of the second. In this way, the classroom is no longer cut off from the home. The mother tongue insinuates itself into the foreign one, blurring the lines between what is inside and what is outside the school. English thus reframed is no longer simply a weapon of colonial conquest. In the hands and on the mouths of Filipino teachers and students, it becomes a language for accommodating, or at least signaling the insistent presence of what was supposed to be excluded and overcome. Conserving the foreigness of English also meant making room for the recurring traces of the vernacular. ${ }^{9}$ 
For the Americans, however, the Filipinization of English was a source of acute annoyance. It was the symptom of the dismal limits of colonial policy and evidence of the racial incapacities of Filipinos. Their "Malay dialects," so different from American English, had the effect of converting their own native tongue into a kind of foreign speech. Filipinos had in effect forced English to appear in drag. Particularly egregious from the American perspective were the "sound mutations" that Filipinos performed on English, resulting in veritable sonic monstrosities. Conducting a series of long and detailed tests among thousands of students through many parts of the archipelago, the Survey categorized and quantified these phonetic mutations. They considered them to be grave errors that had to be "eradicated" if Filipinos were ever to achieve fluency in English:

If American English is to become the language of the school and eventually the Islands, teachers must work hard to correct these errors... They must learn to say: is, was, and has instead of iss, wass, hass; can instead of caan; river instead of reevair; servant instead of serbant; go instead of gu...stream instead of strim; of instead of off; put instead of poot; the instead of de; late instead of let; pen instead of pin; tooth instead of tut; progress and perceive instead of frogress and ferceive. (158-159)

And so forth.

For other Americans, Filipinized English was more than a source of annoyance. Some experienced it as a violent assault. There is, for example, the case of Jerome Berry a former American school teacher and superintendent in Albay province in 1918. In an essay titled "A Little Brown Language" published in the 1927 issue of American Speech, ${ }^{10}$ he describes instances of Filipino teachers' written and spoken English. These amount, he claims, to the "perversion, contortion and mauling [of] our familiar phraseology out of most of its intelligibility. .." Filipino teachers are guilty of,

years of malpractice...in mispronunciation so far-fetched that only one trained by experience could recognize he was not speaking a strange and esoteric jargon.... For Filipino English as it is spoken needs but a stride or two to become a foreign language. At present an American requires a brief period of training before his ear can interpret these strange utterances as a version of his mother tongue. $(15 ; 20)$

Two decades of colonial education in English has thus produced not the hegemony of English but its transformation into a language foreign to the Americans themselves. Vernacularizing the foreign, Filipinos sustain the work of translation, disorienting their American interlocutors. Indeed, Barry blames the unending operation of translation for obscuring thought and confusing conversations 
between Filipinos and Americans: "Naturally much of his thinking... must be conceived in the native dialect, and laboriously translated into English" (16). The result is that "in conversation, the necessity of translation and the frequent literal rendition of native locutions result in many misunderstandings" (Barry 16).

Expecting the Filipino to speak in his, that is, the American's language, the latter instead gets back something else: not English as he recognizes it but the sense of translation at work. It is not, therefore, the Filipino subject that emerges, master of a foreign tongue with which to make plain his thoughts to the American. Instead the latter is confronted with the relentless movements of the speaker, moving back and forth between his own and the other's language. What comes across is neither the meaning of words nor the settled identity of the speaker and the hearer but rather the sense of the unstable and shifting relationship of languages to one another and to their users. Translation results not in the emergence of thought but in the spread of "misunderstanding." This misunderstanding, however, is not meaningless. It consists of sending out certain messages. It signals to the American interlocutor, for instance, not only the on-going labor of translation but also the desire for communication on the part of the Filipino. It is a desire that forms around the conjunction rather than the separation of English from the vernacular. Communication tenuously linked to comprehension, connection loosened from linguistic hierarchy: this is the war of translation that the Filipino brings to the American. It is one where the vernacular escapes the physiological control of the native body and the pedagogical supervision of the American teacher, smuggling its way into the spaces of English, transforming its sounds and displacing its referents. In the on-going war of translation, misunderstanding proliferates. Rather than defer to thought, language indefinitely postpones its arrival, suspending the authority of both the speaker and the interlocutor over the scene of communication.

Faced by this disconcerting onslaught of what Barry deprecatingly refers to as the "little brown language," what is the American teacher to do? Is there a place where he can retreat and escape the "diverse and astounding quackings" of his students who violate English with their "untrainable tongues," where even the most attentive ones are prone to such utterances as "Oh, seer, weel you geeve me bock my pod of pay-pairr?" (Barry 19). There is, according to Barry, one area of English where the native cannot go. It is a region of speech where Americans can converse among themselves confident in the thought that they will remain unintelligible and thus free from the assaults of Filipinization. This zone of safety is American slang. Given the "bookishness" of Filipinos' English vocabulary, she cannot hope to penetrate the "slang and colloquialisms that are current in our everyday speech" (19). It is precisely because of its currency-its swift changes of meaning as these come in and out of fashion, drawing boundaries around some speakers while excluding others - that American slang can have a specificity impervious to Filipinization. As highly contingent, largely anonymous and temporally transient speech acts, slang retains a singularity that makes it seem untranslatable. Hence, Filipino attempts 
to use American slang are bound to sound absurd, according to Barry. To prove this, he cites a letter from a school teacher in Capiz complaining to his American supervisor. Wanting to communicate his anger in English, the teacher ends his letter with "For the love of mud, kid, and why do you do me this way? Dog gone! Great scott! Yours very truly, etc." (17-18).

The laughable conjunction of colloquial expressions with rhetorical deference proves to Barry that American slang "is a sealed book to the ordinary native, educated though he may be" (17). Barry, however, cites one exception: the "Manila cochero" or coach driver. He has become "a master of the profane." We can imagine the uneducated cochero, plying the streets of the city, picking up passengers, dodging pedestrians and other calesas. Overhearing conversations in English, he intercepts profanities, hurling them at others when he has the chance. Out of school, he nonetheless learns a kind of English, one that is familiar to Americans but closed off to most other educated Filipinos. It is not hard to imagine the Manila cochero as part of the "masses" that Constantino describes as "inarticulate." Cocheros, tinderas, cargadores, criados and other workers may have attended a couple of years of school, but more likely none at all. They were supposed to be reduced to passive acquiescence and confused speech by the hegemony of English and the neglect of the vernaculars. And yet, they seem at least from this American account, capable of mastering the most inaccessible aspect of English. What do we make of this seemingly flippant observation? Where else can we find evidence of what Constantino referred to as the mass "appreciation" of the sound of English, or what Barry calls the mastery of its most profane aspects? In what way do such appreciation and mastery reflect popular practices of translating the foreign beyond the confines of schooling and condemnations of nationalist criticism?

\section{Tagalog Slang and the kinship of languages}

Let us go back to the figure of the Manila cochero. Traversing the city's streets, he inhabits a space that is betwixt and between the school and the home. He no doubt would have a place to call home and perhaps would have had one or two years of schooling. But his work situates him in between and at the boundaries of these two places. For this reason, he moves between the affective hold of the mother tongue and the war of translation waged daily in the school. As a denizen of the streets, he has presumably a different perspective from where to grasp the politics of language that is at the heart of both colonial and nationalist discourses. It is a perspective that no doubt grows out of the conditions of his labor: moving back and forth various points of the city, picking up and conversing with all sorts of passengers, surviving on small change, dodging and dealing with corrupt cops, competing with and cooperating with fellow cocheros, and so on. Physically mobile, socially marginal, and economically precarious, the cochero is also, by dint of his promiscuous interactions with people on the streets, linguistically versatile. $\mathrm{He}$ 
"appreciates" the sound of words he may not understand while proving to be adept at mastering invectives and profanities in English, Spanish and other vernaculars. And because he is outside the authority of the school and the maternal conventions of home, he is free to speak in ways that would be intolerable in either place. That is, he can slip away from the linguistic hierarchy that governs the mother tongue (replete with honorifics and an elaborate rhetoric of deference) and the school (with its never ending combat between English and the vernacular). The cochero's linguistic freedom opens up certain expressive and historical possibilities. How do we know this? Where could we go, which calesa can we take to get a glimpse of language freed from hierarchy and thus available for other yet to be determined uses? One such place might be the journalistic writings of Nick Joaquin (1917-2004)

No other Filipino writer since possibly Rizal was better at chronicling the history of everyday life than Joaquin. Widely regarded as one of the best Anglophone novelists, playwright, and poet, Joaquin also wrote a series of imaginative historical essays. Writing under the pseudonym of Quijano de Manila, Joaquin produced a series of journalistic accounts, always historicizing contemporary political and popular culture. While he comes from the same generation as Constantino and went to colonial public schools, Joaquin never had an academic degree and never regarded himself as part of a political vanguard or a nationalist intelligentsia. He was born to a wealthy family-his father was a successful lawyer, a veteran of the Revolution who was close to General Emilio Aguinaldo; his mother a teacher of Spanish and English. But when he was a young boy his father lost his wealth through a series of bad business investments. He quit school and before the war worked as an apprentice for the English language newspaper, The Tribune. He also worked a series of odd jobs from stage hand at a vaudeville company where his brother played the piano, to a proofreader and copyeditor at The Free Press after World War II. Beginning in 1943, and especially through the decades after the war, Joaquin's literary career flourished. He won several prestigious prizes, including being named National Artist of the Philippines for literature in 1976.

Notwithstanding his fame, Joaquin never lost an affinity with street life. His biographers describe his daily habit of taking long, solitary walks through Manila's streets. He delighted in observing the details of urban life, forgotten monuments and local gossip. "He absorbed everything he saw," wrote one of his biographers, "drawing in every sound, every tune heard, from Mexican canciones to American jazz number. . . He danced the tango and spoke the latest kanto boy (i.e., street corner) slang." "11 There was no topic too lowly for Joaquin. As a reporter, he took on assignments of all sorts, from crime stories to celebrity profiles. He was at home everywhere: from the presidential palace to political rallies, from the boxing ring to receptions for visiting dignitaries. As the editor of various weekly magazines, he spoke with everyone, from janitors to typesetters and in 1971, even led a writers' labor union. Joaquin once described himself in the following terms: 
I have no hobbies, no degrees; belong to no party, club or association. I like long walks, any kind of guinatan [stew in coconut milk], Dickens and Booth Tarkington, the old Garbo pictures, anything with Fred Astair . . .the Opus Dei according to the Dominican rite, Jimmy Durante and Cole Porter tunes ... the Marx Brothers and the Brothers Karamazov; Carmen Miranda; Paul's Epistles and Mark's, Piedmont cigarettes ... my mother's cooking...playing tres-siete [a card game], praying the Rosary and the Officium Parvum [i.e., Little Office, or prayers to the Virgin Mary]. . ${ }^{12}$ (qtd. in Mojares 5)

Joaquin was thus an omnivorous consumer of cultural and religious goods, as well as a keen observer of the quotidian rhythms and obscured currents of city life. He was a kind of Filipino flaneur, taking his time and his pleasures wherever he found them. Whether writing about early Spanish colonial history or the political and cultural celebrities of his day, Joaquin kept to a notion of history where the past was always current, the present always haunted by the future becoming past, and where modernity was not the negation of tradition but its fictive kin, its compadre.

In 1963, or around the same time that Constantino's essay had been written and was waiting to appear, Joaquin wrote a piece, "The Language of the Streets." ${ }^{13}$ It was similarly caught up in the post-colonial obsession with language and nationhood. But unlike Constantino's view of mis-education in English as historical tragedy, Joaquin provides a radically different and far more joyful account of linguistic history, one that gives the cochero and others like him their due. It is an essay that has been overlooked perhaps because of the ways it slides away from accepted colonial and nationalist views. It is precisely for this reason that it bears close reading.

Joaquin begins not by continuing to wage the Filipino-American war over the legacy of English and colonial education as Constantino does. Instead, he invokes the American literary critic and journalist H.L. Mencken on slang to buttress his argument that "slang, once scorned as the bastard of language, has risen to the status of heir of the house and begetter of literature" (3). With Mencken, Joaquin proposes to treat slang or what he calls "the language of the streets," not as a "debased" or inferior version of standard speech but as the very basis of a national literature. He focuses particularly on Tagalog slang which he claims has long been the "common possession of Filipinos." As a lingua franca, it forms the basis of the true national language:

It in fact is the national language, not Filipino, [one that is] a natural growth from below, not a decree from above. This language ... is the most daring, the most alive, the most used language in the country today.... [It] is being created by the masses, out in the open, to express their lives, to express their times, and just for the fun of it. That's why it promises to be a great 
language: because it's being created for the sheer joy of creating. Happyhappy lang! (Joaquin $4 ; 18$ )

That a national language has emerged outside the control of official academies and colonial education suggests the workings of a history missed by critics of miseducation. How can Tagalog slang serve as the basis for the national language? It is because slang, according to Joaquin, works like a lingua franca. It travels across linguistic and social boundaries with great speed, thanks to the commercial mass media, enabling speakers of various vernaculars to understand one another. In this way, Tagalog slang assumes the historical legacy of Spanish. Herein lies another startling contrast with Constantino. Where the nationalist holds on to the notion of languages as mutually discrete and arranged in a hierarchy-Spanish or English historically and oppressively lording it over the vernaculars-Joaquin sees the colonial language of Spanish at the basis of Tagalog slang, indeed of all Tagalog as it is currently spoken. Such a view is consistent with a recurring theme in Joaquin's literary and historical writing: that the colonial is inextricably wed to the national as the latter's condition of possibility. "Spanish," he writes, "is not dead in the Philippines. We unknowingly speak it every moment of our lives" (Joaquin 12). Castilian loan words such as "calle, mesa, tren, pier, vapor, libro, coche, cine, gobierno, Dios," permeate nearly all Philippine languages. Unlike indigenous words which are genetically related but distinct in their spellings and pronunciations, Spanish words are immediately recognizable across vernaculars (Joaquin 4). This great loan of words has accrued enormous interest over time, investing vernacular languages with something in common. What was once the language of imperial authority has come to be parceled and circulated, borrowed and shared to provide "the foundation of a national language" (Joaquin 4).

Here, the power of Spanish is felt most acutely when it has become powerless to command. It has been detached and broken up from its original speakers and woven into the fabric of local languages. The foundational significance of Spanish then lies not in its ability to dominate the vernaculars from above or to serve as their horizon of their reference. Rather it has to do with its capacity to connect and conjoin them while leaving them distinct. It allows, that is, for the recognition of something held in common among languages without reducing their differences. There is ample historical evidence to support Joaquin's assertion that Spanish, or at least its vernacularized versions, have long provided the basis for the country's lingua franca. The Spanish missionary decision in the sixteenth century to evangelize in the native languages required, among other things, converting the pre-colonial writing system into Latin script, while embedding many bits and pieces of Castilian words untranslated, such as Dios, Virgen, Spiritu Santo, etc. into the local languages. They feared that substituting these words for the most sacred referents of Christianity with vernacular terms would lead natives to confuse them with local religious concepts as in the case of indios in the Americas. ${ }^{14}$ One result: 
native literacy now meant reading her own language in the script of another, all the while navigating through the charged, because foreign, bits of Castilian strewn throughout local languages. By the late eighteenth and through the nineteenth century, lowland vernacular literature such as those in Tagalog had become permeated with Castilian. Even that most canonical of Tagalog poets, Balagtas, (who worked as a court translator and was fluent in Spanish) wrote his epic poem, Florante at Laura in a Tagalog that had so thoroughly vernacularized Castilian that it was easy to forget, as many of his late twentieth and twenty-first century readers have, that the power of his language was the product of centuries of Castilianizing the vernacular. ${ }^{15}$

Through three and a half centuries of Spanish rule, many other non-religious Castilian words seeped through the vernaculars, becoming indistinguishable parts of their vocabulary. By the late nineteenth century, as Rizal's novels show and as scholars such as Emanuel Luis Romanillos and Benedict Anderson have pointed out, a mix of Spanish, the vernacular like Tagalog and a Chinese language like Hokkien had amalgamated into a lingua franca known by many names: espanol de Parian, chabacano or lengua de tienda, for example. It had become widespread in Manila and its surroundings as well as in other port cities in the Philippines. This creole language grew around the market place, spread throughout the streets, travelled up and down the social hierarchy and was quickly picked up by new arrivals from Europe. Rizal himself used it in a few of his personal correspondences with fellow ilustrados, and his second novel has numerous examples of characters-Spanish friars, Chinese merchants, devout india women, mestizo students and anonymous voices in the crowd--speaking it fluently. As Anderson describes it, espanol de Parian [i.e., the Spanish of the Parian, the Chinese quarter designated by the Spaniards just outside the walls of Manila] was "a real, Hokkien-inflected lingua franca for the streets of Manila, egalitarianly shared by poor vendors and their elite student customers. A patois... but also an instrument of social communication, not an emblem of political shame"16 (79). It continued to survive and even flourish in many parts of the country in the wake of the American invasion and occupation, especially in the Ermita district till the end of World War II, and is still spoken in parts of Cavite, Cotabato and Zamboanga. ${ }^{17}$

Tagalog slang, Joaquin argues, is the proper heir to what he calls Spanish, or what historically was espanol de Parian. ${ }^{18}$ It "flows" through all the local languages, but acknowledges neither source nor directive. It comes instead from "the anonymous word-coiners on the street" who through no coordinated or systematic efforts nonetheless "are doing more to speed the coming of a common tongue than all the schools and the academics put together" (Joaquin 5). If this is the case, then the foundational status of Tagalog slang, like Spanish, will have to be qualified. They cannot be seen to form a firm bedrock on which the national language is built but shifting and contingent nodes linking various languages as in a network. Slang as the contingent foundation of a common speech operates in a distributive 
and decentralized fashion. Hence, it can only have variable and unknown authors, obscure and unverifiable origins, indiscriminate interlocutors, along with uncertain and erratic life spans. This "coming of a common tongue" feels like a messianism without a messiah. It has always already happened, but it is always yet to arrive.

In coming, this common tongue shows its power to register particular moments in the nation's historical becoming. Constantino as we saw feared that colonial education through English would obliterate the true history of the country's anticolonial struggles. Joaquin sees a possible antidote to this amnesia in Tagalog slang's capacity to "sum up a whole period." It does so by its rampant theft (for this is one of the purported origins of the word "slang") of other languages, including other vernaculars. For example, there is sipsip buto from Ilocano, popular in the 1930 s to denote the political sycophants that surrounded Commonwealth president Manuel L. Quezon); genoowine from the English "genuine" widely used during the Japanese Occupation to refer to anything good and of great value; and the withering Hanggang pier ka lang, "He's only taking you as far as the pier," often heard during the American re-occupation of the country after the war addressed to Filipina women having relations with American servicemen (Joaquin 18). Joaquin excavates other linguistic artifacts that preserve the fleeting images and sensations of other eras: from the 1920s, stambay (bum, lumpen) who could easily become a thug or maton, sanggano, and butangero (6). In the 1930s, a new social type emerged: the fashionable man about town, cocksure and a touch arrogant, known as hambug, sikat, siga-siga, while the new urban experience of going out on the town was referred to as naggoo-good-time, that is, "having a good time"(Joaquin 8-9). Flash forward to the late 1960 os and 1970 s when class replaced genoowine, the female organ was called kepias, jingle was to urinate, jakol was to masturbate and massage parlors began to offer sensation, "a cryptonym for orgasm as in: Masseuse to customer: 'gusto mo ba ninyo ng sensation?"' Would you like a sensation? (Joaquin 21) The formative years of a new gay culture is archived by such words as "T-Y (thanks), sibai (call boy), serbis (paid sex), and type (somebody you're aroused by)" (Joaquin 19) as well as the all-purpose affirmation, "Anong say mo?" What do you say! The history of the drug culture which accompanied the influence of American youth culture in the Philippines is embedded in the numerous terms for getting stoned as in trip, durog, durog na durog, shotgun, iskor (i.e., to buy drugs), bitin (not high enough), high na high (very high) and its synonyms, banggag, sabog, and basag (Joaquin 19-20). Joaquin sums up the whole era with the word that replaces the 1920 siga: jeproks, "which can mean anything from hippie to mod to rebel to flamboyant [youth]" (21).

For Joaquin, cataloguing slang terms provides hurried glimpses into a history of emergent social types, novel sub-cultural formations, popular practices around fashion, sex, leisure and consumption. These words are shards which do not necessarily add up to a whole. Instead they remain fragments of larger narratives yet to be written, the traces of social histories that may never be told. 
Here, language does not reveal historical truth which brings self-knowledge and national redemption. The bits and pieces of slang instead suddenly trigger the recollection of the past as fractured, inconclusive moments through a series of linguistic associations. One slides gleefully from trip to durog to durog na durog, to banggag, to basag, to jeproks, and so on without pausing to think what they all mean, only that they stimulate more associations. These chains of associations are potentially endless and so are likely to be of little use to nationalist historiography. In the drama of nationalism, as explicated by Constantino, language linked to education are matters of life and death. The very survival of a people are at stake in the future of English and the national language. By contrast, Joaquin's linguistic history suggests something else is at play. Tagalog slang in "summing up an era" converts the past into language, that is, into a series of expressive possibilities over which no one has the first or final word. By reconfiguring the past into an ever expanding constellation of associations, Tagalog slang for Joaquin opens up speech and loosens the grip of linguistic hierarchy. Such a development leads, arguably to the very democratization of society that Constantino had longed for. The basis for a common language emerges through the sudden but recurring appearance of slang, converting the most mundane and abject aspects of life into rich and commonly available sources of the literary.

To see these literary possibilities at work, we can look at the following example. Joaquin explicates the Tagalog term barkada, made up of one's closest friends, at times referred to as ka-rancho (that is, from the same ranch) or chokaran (the syllabic inversion of ka-rancho). Popular since the 1950s, the term comes from the Spanish barco, or boat, which brings it in association with the pre-colonial Tagalog barangay, the word for boat as well as village. But Joaquin does not stop at translating barkada into English. He deploys it alongside related slang terms. In the process of talking about barkada, he begins to tell a story not only about its possible associations but of the network of other words which lead away from these associations:

When a barkada has an atrazo that means trobol, a rambol, a golpehan, also described as balasahan, or shuffle. In a good barkada, every member is kumakasa or fighter. . A kumakasa would rather be tepok-that is, killedthan find himself turned into an under, or stooge. Such a fate is diahe, or hadya, slang's coyer version of a major Filipino term: hiya, shame.

But a barkada's chief foe is always the law, represented by the policeman who is known as lespo, alat [i.e., tala or star spelled backwards, a reference to his badge] or-this is the latest term-parak. Alagad ng batas [i.e., officers of the law] is, like all formal Filipino phraseology, uttered only with a smile.... When the alat appears it's best to batse or sebat, derivations from the Spanish se va and pase. If you don't botak fast enough, you end up in Munti [i.e., Muntinglupa, the penitentiary] and your chokarans explain you're na sa loob 
[inside] where if you're guwapo [i.e., good looking] you may find yourself forced to become some tougher convict's senorita. But if you're ugly-askdad is the word for it-you'll still have to pay tribute in the form of yosi (cigarettes) or maman (liquor) or atik (money).

Atik, one of the most used expressions today is the Tagalog word for earnings, kita, spelled backwards. A guy with a lot of money is maniac; to be broke is to lawang-lawa. The old term for extortion, diligencia, has been joined by kikil (to chisel) and arbor (an anagram of robar). Nakatipak is to hit the jackpot; and tipak na tipak is to be in the chips. Then you can buy toga (shoes) a polo (shirt) or even a cana (coat)... And you can go into a restaurant and eat without having to do the one-two-three, which is to flee or poga (from the Spanish fuga) after eating without paying the bill.

To eat is enka, chicha, hatchit...To drink is to toma, maman, and barik...If the erbi, cuatro cantos, markang demonio, birginrum or white label goes to your head, you're groggy, wango, enggot, senglot or pass-out. (Joaquin 13-15)

I could go on but will resist the temptation to quote many other similar passages in the essay. Reading the section above, or better yet reciting it out loud, one gets an acute sense of what Joaquin says are the characteristics of Tagalog slang: its speed, its spontaneity and its remarkable capacity to "absorb without fuss" terms from other languages, including Tagalog itself (3). The speed of slang's transmission, enabled by mass mediated technologies and the spread of the marketplace, endows even familiar words with a recurring novelty. One senses this in the rhythm of Joaquin's telling. He begins with barkada but is quickly off to other words: atrazo, trobol, rambol, golpehan, etc. What emerges is a kind of accidental narrative about a barkada settling a score or atrazo, then getting into trouble with the law or lespu, being sent to jail, Munti, having to pay off guards and other prisoners with yosi, cigarettes or atik, money. The last word, atik, triggers another chain of associations: earnings, kita, extortion, diligencia, theft, arbor, that in turn opens up another set of linkages: jackpot, nakatipak, shoes, toga, going out and eating, chicha, that leads to several words for drinking, alcoholic drinks, then getting drunk. It is as if in talking about slang, one ends up talking in slang. One is contaminated by its metonymic pull and disdain for linguistic conventions. Like the barkada that has to botak fast enough from the lespu after settling an atrazo, slang evades the institutional authorities of home and school. It is impatient to move on, as Joaquin does, jumping from one word to another to string together less a story about the national language as an enactment of its expressive possibilities.

A significant aspect of this enactment has to do with translating slang into English. Joaquin obviously has a Filipino readership in mind, one literate in English and schooled in precisely the kind of colonial learning that Constantino had lamented. Addressing these putatively mis-educated Filipinos in the 1960 and 1970s, Joaquin sought to describe for them what perhaps they already knew from 
hearing and using Tagalog slang, but the importance of which they were barely aware and could not acknowledge. For Constantino, as we saw, mis-education in English impaired thinking by impeding the translation of language into thought. Instead, like American colonial officials, the nationalist bemoaned the failure of translation to work properly, that is, to make language, both English and the vernacular, into transparent and servile instruments for the formation of a self in control of its own thoughts. Mis-education meant that colonial education continued in the postcolonial classroom characterized by the war of translation. In seeking to replace English with Filipino as the more effective medium of instruction, Constantino sought to win this war-to stop language from posing obstacles to learning by putting an end to the need for translation. Hence, for the nationalist who inherits the colonial legacy, the answer to the war of translation was similar to the latter's: a war on translation.

In Joaquin, translation has a different trajectory. In the passages above, Joaquin translates Tagalog slang into English. But as we've seen, the English prose is punctuated and punctured by the speedy and restless appearance of slang to the point where the English sometimes blurs into Tagalog. The power of slang to absorb and displace all languages affects the very language that is seeking to capture and objectify it. English is repeatedly ensnared in slang. Most of the time, Joaquin provides approximate English equivalents to the Tagalog. At other times, the chains of associations move so rapidly as to carry away the English, as when the writer himself is carried away to the point of dispensing with translation altogether:

There was a time when you could say nothing without having some wise guy flatten you with 'May nothing ba sa cano?' The ritual retort to this was 'Wala, sa Bombay mayroon, hulugan pa?' The current whoop is: "Uy, sa akin yata yan!' Last year produced 'Sino ang kaaway mo?' and 'Sabi mo, eh!' But the prime product of the year is 'Happy-happy lang!' To make happy-happy is to drink together, and the lang means: 'No trobol.' (Joaquin 17)

In the passage above, entire English phrases are left untranslated as if there was no need for Joaquin to tell his mis-educated readers what these meant. And when he does pause to translate the word lang (i.e., only, merely, simply), he does so with another slang word, "No trobol?" Tagalog slang has taken over English not by situating itself above but by folding itself into its syntax and spelling. "Happy" becomes "happy-happy lang!" Freed from the conventions of home and the institutional constraints of school, Tagalog slang makes possible a way out of the war of and on translation. Instead, it allows for translation as promiscuous and on-going play. Veering from the serious responsibilities of an officially mandated national language, Joaquin's translation of the language of the streets is underwritten by an ethos of attentiveness to what is new and what passes for new regardless of its provenance or precise meaning. Such is, perhaps, the basis of its literary promise. Translation 
liberated from the task of reproducing hierarchy is another way of experiencing the nation whether in its colonial or post-colonial state. This indecorous, vulgar, miseducated nation is one were, for example, vaudeville actors, like cocheros, atsays, tinderas, and kanto boys might take their place alongside academics, politicians and landlords to give their own treatise on the national language. We get a sense of what this other nation might be like when Joaquin performs a shtick he doubtless learned from his time working as a stage hand in vaudeville productions. It consists of asking:

Did the English language spring from Tagalog? Yes, averred the vaudeville professors; and they point out that many English words have an obvious Tagalog origin-for example, pussy from pusa, mother hen from inahen. There's something to this theory, really. Those English words, tot and toydon't they clearly come from totoy, the Tagalog for child? And another Tagalog word for tot, bololoy-usually shortened to boloy or boboy-is just as clearly the source for boy. Where would the English suit have sprung from but from our word for wear, suot?... What pronoun came first: the Tagalog ito or the English it?... The friction of our kiskis undoubtedly sparked kiss, as the laceration of gasgas grows bigger in gash, and the dangle of luslus swings again in loose, and the sibilance of sipsip is scissored in sip... But what need we to go on? Even the English word for nurse, nanny, is obviously a derivative of nanay. (Joaquin 17-18)

Joaquin carnivalizes the relationship between the imperial and subaltern languages, placing the latter not only on top but at the origin of the former. This reversal, however, is less about nationalist revenge or resentiment as it is about highlighting what Constantino referred to as the masses' "appreciation" for the sound of English - and, we might add, for the sound of any language. The joke here rests on the fact that the Tagalog words are neither the semantic equivalents nor the etymological origins of the English. Rather, a series of phonic similarities are made to resonate between the two, loosening the authority of English to delimit the vernacular and vice versa. The two are juxtaposed in the mode of call and response: kiskis returns as kiss, gasgas calls forth gash, luslus yields loose, sispsip breaks into sip. In retailing this "venerable theory," Joaquin seizes another opportunity to show the literary potential of Tagalog slang, that which makes it the basis of a national language. ${ }^{19}$ Such potential, as I have argued, consists of mobilizing the practice of translation as play. It means being alert to the materiality of languages, beginning with their sounds. Translating after a fashion Tagalog into English reveals neither their semantic equivalence nor their relative capacities for civilizing bodies or yielding thought. Rather, as Joaquin shows, it demonstrates their fleeting kinship. As if descended from Tagalog, English like Spanish gives up its power to command and order native speech. It becomes, instead a kind of relative, perhaps a friend, a 
chokaran, a member of the barkada of Tagalog slang. Together they come to share something in common, forming the basis for a kind of national language. Happyhappy lang! 


\section{Notes}

1. The most engrossing biography of Renato Constantino is by Rosalinda Pineda Ofreneo, Renato Constantino: A Life Revisited, Quezon City: Foundation for Nationalist Studies, 2001, especially 16-55, 70-129. The quotation is on 159. Ofreneo conducted long interviews with both Renato and his wife, Letizia Roxas as well as with his children, Renato, Jr. and Karina and their spouses and their grandchildren. She was also afforded access to his "Memoirs," scrapbooks, letters and family photographs.

2. Ofreneo, Renato Constantino, 158-184. Worth noting is a recurring feature of Constantino's life: that it was fashioned within the very structures of Englishlanguage colonial education and bourgeois privilege of which he would become a harsh critic. For example, all three of his mother's sisters were school teachers in colonial public schools. They spoke English and delighted in the American popular culture of their time in contrast to his maternal grandmother who spoke Spanish and regarded Americans with fierce hostility.

Constantino attended colonial public schools, graduating from Arellano High School and continuing to the University of the Philippines. Both schools had been sites of student protests: in Arellano against the racist behavior of its American principal; in UP against the conservatism and proto-fascism of Commonwealth President, Manuel L. Quezon. Constantino was also the beneficiary of Filipino elite politics. His left wing thinking occurred against the backdrop of his marriage to Letizia Roxas, whose family owned extensive properties in Manila and Aklan province, whose father was a well-known lawyer (like Constantino's), and whose uncle was no less than former House Speaker and first President of the Third Republic, Manuel Roxas. He owed his job at the Department of Foreign Affairs to the Foreign Secretary Carlos P. Romulo who had met him while he was a student at UP. Thanks to the intercession of Senator Claro M. Recto, the wealthy landlord Eugenio Lopez, and no doubt, due to his wife's familial prominence, he managed to elude jail time unlike some of his other left-wing friends (e.g., Angel Baking). While he suffered from the communist witch hunts of the 1950 and early 1960 os in part for his refusal to cooperate with the military, he was eventually given a job by the Lopez family, first serving as an economic researcher at the Binalbagan-Isabela Sugar company (Biscom) in 1955, and more significantly as the curator and director of the Lopez Memorial Museum from 1960-1972 where he would hone his skills as a historian and write several major works revising Philippine history. See Ofreneo, 1-15; 36-53; 54-69; 109-157.

Constantino's life testifies to the contradictions inherent in the history of left-wing nationalist intellectuals, beginning with late nineteenth century ilustrados. Direct beneficiaries of the economic, cultural and political structures put in place by colonial rule, they nonetheless find in this inheritance the very resources with which to negate it, crafting a language of refusal of and resistance to its unjust workings. Ironically, their ability to sustain such resistance continues to be predicated, as with other Filipino nationalist elites, on their 
ability to call upon the protections and patronage of the very system of colonial and neo-colonial rule-and the cultural-educational system that reproduces it-on their behalf. Thus, even in the darkest days of Constantino's life, he was able to hide out during the Japanese Occupation in remote provincial locations, thanks to peasants working on lands owned by his family in Bulacan. While in the midst of the anti-communist witch hunts in the 1950s, he was also able to play tennis at the Philippine Columbine Club and live off rents collected from apartments he had himself designed in the Manila properties he and his wife owned, and of course eventually get jobs with the Lopez companies and museum. When Martial Law was declared in 1972, he evaded the fate of many other antiMarcos opponents, escaping detention through the intervention of a Marcos ally, prominent journalist Doroy Valencia, who was a good friend of his father. He was instead consigned to house arrest until 1975.

It is also worth noting that as an ilustrado male, he benefitted enormously from the physical and emotional labor as well as devoted loyalty of his wife. Letizia served in many cases as his researcher, typist, and most sympathetic reader-in many ways his co-author as he would belatedly acknowledge in later works. She recalls how her husband, once comfortably ensconced as director of the Lopez Museum and Library, found the thirty minute commute to his office in his chauffeured air-conditioned car boring. Unable to read because of his car-sickness, he asked her and daughter Karina to record entire books which he could listen to on the way to work. Among his favorites was a book recounting the life and struggles of Che Guevarra and his brave attempts to elude capture. The irony boggles the mind. It is as if "mis-education," as Constantino called it, always harbored the means not only for its critique but also for its constant reformulation and ever exquisite refinement.

3. See Ofreneo, 16-35, 70-8o to get a sense of the anti-colonial, Marxist-nationalist motifs that inform his university and post-war writings. For the American colonial influences, see my discussion below. One wonders too if its title may have even owed something to the 1933 book by one of a small number of African Americans who taught in the Philippines, the historian Carter Woodson, The Mis-education of the Negro, re-published by Trenton [NJ]: Africa World P, 1990.

4. For a more detailed discussion of ilustrado nationalism, see Vicente L. Rafael, The Promise of the Foreign: Nationalism and the Technics of Translation in the Spanish Philippines, Durham: Duke UP, 2005; and Resil Mojares, Brains of the Nation: Pedro Paterno, T.H. Pardo de Tavera, Isabelo de los Reyes and the Production of Modern Knowledge, Quezon City: Ateneo de Manila UP, 2006; Benedict Anderson, Under Three Flags: Anarchism and the Anti-Colonial Imagination, London: Verso, 2005. Anderson offers a pointed critique of Simoun's European romantic nationalist views about the need to install one of the vernaculars as the national language while setting aside all other vernaculars, including vernacularized versions of the colonial language. He says in perfect Spanish the need to reject Spanish, although he remains vague about which of the vernaculars were supposed to replace it. Constantino, writing more than half a century later and in the wake of the Commonwealth attempts to install Tagalog 
as the basis of Filipino, has no qualms about which local language should replace English. But like Simoun speaking in fluent Spanish, he makes this argument in impeccable English so as, presumably, to reach precisely those English-speaking, mis-educated Filipinos he rails against. See Benedict Anderson, Why Counting Counts: A Study of Forms of Consciousness and Problems of Language in the Noli Me tangere and El Filibusterismo, Quezon City: Ateneo de Manila UP, 2008, 83-85.

5. Jose Rizal, El Filibusterismo: Novela Filipina, Ghent: Boekdrukkerij F. Meyer-Van Loo, 1891, chapter VII, 47. English translation cited in Constantino, 30.

6. Najeeb Mitry Saleeby, The Language of Education of the Philippine Islands, Manila, P.I.: N.p., 1924, quoted in Constantino, 32. For a related critique of the limited utility of English, see also the speech of Vice-Governor and head of the Bureau of Education, George C. Butte, "Shall the Philippines Have a Common Language," Manila: Bureau of Printing, 1931, especially 14-14 and 19-20.

7. Paul Monroe, Board of Educational Survey, Philippines, A survey of the educational system of the Philippine Islands by the Board of educational surveys: created under acts 3162 and 3196 of the Philippine legislature, Manila: Bureau of Printing, 1925.

8. See May, Social Engineering, 83.

9. For an early colonial Tagalog precedent for this linguistic practice, see Vicente L. Rafael, Contracting Colonialism: Translation and Christian Conversion in Tagalog Society Under Early Spanish Rule, Durham: Duke UP, 1993, especially Chapter 2. 10. Jerome Barry, "A Little Brown Language," American Speech, 3.1 (1927), 14-20.

11. For the most informative biographical information on Joaquin, see Resil Mojares, "Biography of Nick Joaquin," (1996) http://www.rmaf.org.ph/Awardees/Biography/ BiographyJoaquinNic.htm; and Marra PL. Lanot, The Trouble with Nick and Other Profiles, Quezon City: U of the Philippines P, 1999, republished in bulatlat.com, http://www.bulatlat.com/news/4-13/4-13-nick.html

12. Mojares, "Biography of Nick Joaquin," http://www.rmaf.org.ph/Awardees/ Biography/BiographyJoaquinNic.htm, 5 .

13. "The Language of the Streets" first appeared in 1963, and has been republished in Quijano de Manila, The Language of the Streets and Other Essays, Manila: National Bookstore, 1980, 3-21.

14. See Rafael, Contracting Colonialism, especially chapter 1.

15. See Rafael, The Promise of the Foreign, chapter 6.

16. Benedict Anderson, Why Counting Counts: A Study of Forms of Consciousness and Problems of Language in Noli me tangere and El Filibusterismo, Quezon City: Ateneo de Manila UP, 2008, 79. See also Emmanuel Luis Romanillos, "El Chabacano de Cavite: Crepusculo de un Criollo Hispano-Filipino?” Linguae et Litterae 1, Dec. 1992, 9-14. See also Carmen Guerrero Nakpil's account of speaking Ermita Spanish during the 1930s in her autobiography, Myself, Elsewhere, Manila: Circe, 2006, 75-76.

17. Indeed, as Anderson conjectures, had the United States not arrived and the First Republic allowed to survive, Spanish would have become one of the official languages of the state while "a kind of Filipino Spanish would have become, de facto, either the official language or the country's lingua franca." It would have 
been one that, as Joaquin would say regarding Tagalog slang, a language that would be "open to everyone to adapt it, corrupt it, change it in accord with local needs." Anderson, Why Counting Counts, 84; 86.

18. Joaquin, like many others who have written about Tagalog slang or Taglish, elide the presence of Hokkien contributions to the lingua franca or national language in the same way that they tend to repress the profound Chinese presence in Philippine history.

19. This "venerable theory" of language, one predicated on translation as play, dates back further than the introduction of vaudeville to the Philippines. See for example, the awit or songs of the sixteenth century ladino, or bi-lingual poet, printer and translator for Spanish friars, Tomas Pinpin as discussed in Rafael, Contracting Colonialism, chapter 2. It is tempting to place Joaquin in the tradition of Pinpin and think of him a post-colonial ladino. It is therefore a mistake, in my view, to treat him, as some nationalist writers have, as an apologist for Spanish colonial rule. The other obvious comparison here would be Jose Garcia Villa, the other great Anglophone writer who chose to live in New York rather than return to the Philippines after leaving in 1927. But that would be the subject of a future essay.

\section{Works Cited}

Anderson, Benedict. Under Three Flags: Anarchism and the Anti-Colonial Imagination. London: Verso, 2005. Print.

--. Why Counting Counts: A Study of Forms of Consciousness and Problems of Language in the Noli Me Tangere and El Filibusterismo. Quezon City: Ateneo de Manila UP, 2008. Print.

Barry, Jerome B. "A Little Brown Language." American Speech 3.1 (1927): 14-20. JSTOR. Web. 2 Feb. 2009.

"Biography of Nick Joaquin." Ramon Magsaysay Award Foundation Online. 1996. Web. 3 Feb. 2011

Butte, George C. Shall the Philippines Have a Common Language. Manila: Bureau of Printing, 1931. Print.

Constantino, Renato. “The Mis-education of the Filipino." The Weekly Graphic 8 June 1966. Rpt. in The Journal of Contemporary Asia 1.1 (1970): 20-36. Print.

Joaquin, Nick. "The Language of the Streets." The Language of the Streets and Other Essays. Manila: National Bookstore, 1980. 3-21. Print.

Lanot, Marra Pl. The Trouble with Nick and Other Profiles. Bulatlat.com 4.13 (2004)Web. 3 Feb. 2011.

Mojares, Resil, Brains of the Nation: Pedro Paterno, T.H. Pardo de Tavera, Isabelo de los Reyes and the Production of Modern Knowledge. Quezon City: Ateneo de Manila UP, 2006. Print.

Monroe, Paul, Board of Educational Survey, Philippines, A Survey of the Educational System of the Philippine Islands by the Board of Educational Surveys: Created Under 
Acts 3162 and 3196 of the Philippine Legislature. Manila: Bureau of Printing, 1925. Print.

Nakpil, Carmen Guerrero. Myself, Elsewhere. Manila: Circe, 2006. Print.

Pineda Ofreneo, Rosalinda. Renato Constantino: A Life Revisited. Quezon City: Foundation for Nationalist Studies, 2001. Print.

Rafael, Vicente L. Contracting Colonialism: Translation and Christian Conversion in Tagalog Society Under Early Spanish Rule. Durham: Duke UP, 1993. Print.

--. The Promise of the Foreign: Nationalism and the Technics of Translation in the Spanish Philippines. Durham: Duke UP, 2005. Print.

Rizal, Jose. El Filibusterismo: Novela Filipina. Ghent: Boekdrukkerij F. Meyer-Van Loo, 1891. Print.

Romanillos, Emanuel Luis. "El Chabacano de Cavite: Crepusculo de un Criollo HispanoFilipino?" Linguae et Litterae 1 (1992): 9-14. Print.

Saleeby, Najeeb. The Language of Education of the Philippine Islands. Manila: N.p., 1924. Print.

Woodson, Carter. The Mis-education of the Negro. Trenton: Africa World P, 199o. Print. 